International Journal of Advanced Studies in Humanities and Social Science (IJASHSS)

Available online at http://www.ijashss.com

Volume 8, Issue 1 (2019) pp. 104-118

Original Article

\title{
The Impact of Financial Constraints and Managerial Entrenchment on the Relationship between Excess Cash Holdings and Investment
}

\author{
Hossein Rahmandost ${ }^{1 *}$, Ali Faez ${ }^{2}$ \\ ${ }_{1}^{1}$ Department of Management, Semnan Branch, Islamic Azad University, Semnan, Iran \\ ${ }^{2}$ Assistant Professor, Department of Accounting, Islamic Azad University, Semnan Branch, \\ Semnan, Iran \\ *Corresponding Author E-mail: rahmandosth@yahoo.com
}

Received: 24 October 2018, Revised: 05 December 2018, Accepted: 20 December 2018

\begin{abstract}
This study seeks to examine the impact of financial constraints on the relationship between the management and investment of excess cash held by companies. A total of 90 companies from the companies listed in Tehran Stock Exchange In the period of 1384 to 1391 were selected for the study after some filtration. The results show that changes in excess cash holdings influence capital expenditure of companies have no financial constraints and the impact it has on companies with fewer financial constraints. Other results concerning the effect of board structure and the influence being strong or weak on spending on capital expenditure, showed that the structure of the Board had a significant positive impact on the company so that it can be said that the strengthening the board structure, led to an increase in the amount invested in the companies in question.
\end{abstract}

Keywords: Financial Constraints, Management And Board Of Directors Structure, Cash Holdings, Investment.

\section{Introduction}

The amount of money held in a company and the size of investment are the factors that are closely related and influence the activities on different levels. A company without cash holdings will experience bankruptcy. On the other hand a company with oversized cash holdings will face other problems such as irresponsible spending of money and an expenditure capital structure. So, many companies may face financial problems holding inappropriate amounts of money (Modaresi and Dianati, 1382). Planning the cash holdings is to improve the managerial strategy which in turn leads to improvement of the efficiency, liquidity power, the power to pay back the debts, and the continuity of operation in the company. It can be considered as one of the most important factors in success or failure of a company (Lee, 2007). Holding cash increases the value of the company 
(Fost, 2004), and is a good reservoir in the cases of unexpected disasters (Resayian et al., 1389). Investors also, punish the companies who hold more cash than needed, because the cash could be invested to benefit the investors (Swanson and Altizer 2010). Studying the effects of financial constraints and the structure of the board on the relationship between investment and cash holdings is the goal being followed in this article.

\section{A Review of Theoretical Literature}

\section{Cash Assets Held}

One of the basic tasks a financial manager is to do is to manage current capital or specifically to manage the cash holdings. Strategies in the companies are set regarding two goals: supplying the needs for cash payments in daily operation of the company and decreasing the stagnant money to a minimum. The latter expresses the concern that if some assets are not used properly there will be no benefit using them. Unfortunately these two goals can be in contrary.

\section{Board of Directors}

Corporations are managed by some shareholders who are called board of directors by the law. These shareholders are representatives of the company and how the company operates strongly depends on these people. If the board of directors is knowledgeable and impartial, shareholders benefit greatly and if the company is to lose the resources they will call for dissolution if the company immediately.

\section{Financial Constraints}

The most comprehensive definition of financial constraint is the following: companies are under financial constraint when there is a gap between internal and external consumption and the allocated cash.

\section{The Optimum Level for Investment}

Equities are continually in situation for investing some of their resources and the decision where to put their money for the optimum outcome. In fact investments should be made where efficient and with regard to the resources. But the important matter is to choose plans and decisionmaking about the opportunities by managers which is made affected by their personal interest.

\section{A Review of the Literature}

Bernard et al. (2013) found out that indexes in board of directors like size, independence, and duplicity of tasks has no significant relationship with the predicted outcomes being more sensible.

Agnes et al. (2010) studied the relationship between company governance and manipulation of profit through the trades with known parties. They concluded that the quality of company governance can influence not using the trades with known parties to manipulate the profit.

\section{Cash Assets Held}

Yanto (2011) examined the relationship between the mechanisms of company governance and company value in Singapore. The findings showed that the companies with a less effective company governance tend to keep more cash in the company. Other findings show that due to flexibility and also the battle between managers and owners, and representation theory, managers keep more cash for caution. In addition companies with a pyramid structure in ownership keep 
lower amounts of cash in comparison with single owner companies and are more valuable.

Sabramanian et al. (2011) studied the relationship between the structure of the company and the amount of cash being held. The findings show that companies with decentralized management structure keep a significantly lower level of cash comparing to those with centralized structure of management. Further studies by them showed that the reason is that companies with decentralized management have a more extended relationship with other companies and the industry so their opportunities for investment are more, so they keep less cash.

Officer (2010) studied the relationship between the relationship between higher rate of investment in cash and dividend and found out that to fight against difficulties of holding great deals of cash and greats deals of investment two ways can be followed. The first is to rebury the company's own share. And the other is to divide the profit and lower the expectations of the shareholders; this will lower the probability of facing the problems caused by oversized cash holding.

Harford et al. (2008) studied the relationship between holding oversized cash and governance structure. Findings show that internally managed companies whose major ownership is internal, keep higher amounts of cash. Meanwhile companies with a higher quality of company governance and more crowded board of directors who are more independent keep lower amounts of cash.

Geni et al. (2003) studied the behavior by the cash. Their findings show that the amount of cash being held in the company is intensively affected by the law structure and ownership structure. They found out that higher degrees of conservatism towards the shareholders is associated with lower amounts of cash being held in the company and also centralization of ownership negatively affects the cash remnants.

Ditmar et al. (2003) conducted a study, findings of which show that in the countries where stockholders are not supported strongly, the cash remnants are significantly high. Also it is evidenced that in these kinds of countries other factors are less effective.

\section{Financial Constraints}

Roka et al (2004) analyzed the problems with oversized investment. They suggested that the potential contrary existing between management, ownership, and investors affects capital structure, company governance, and investment policies and leads to a growing number of inefficient decisions made by the management and non-optimized investments the two of which are the main factors in over/undersized investment.

\section{Data Gathering}

To codify theoretical basis, library method was used and to gather data field study was the tool. Different resources namely; CDs owned by Tehran Stock Exchange, Tadbir pardaze software, and Tehran Stick exchange website were used. Gathered data were adjusted and classified by EXCEL software and final analysis was conducted using SPSS.19 software.

\section{The Population and the Sample}

The population in this study is all the companies which are accepted in Tehran Stock Exchange. To set the sample the following conditions were created:

Investment companies, dealerships, and insurance companies are not qualified, 
financial information for the period under study has to clear, their fiscal year has to finish in Esfand, and the name of the company mustn't be removed from Tehran Stock Exchange and has to be accepted before 2008. After subjecting the population to the conditions 94 companies were chosen for 7 years (624 companyyear) as the sample.

Variables

Dependent variables

\section{Investment Level}

According to Lee and Shi (2010) the expenses of investment are used as an index for investment level.

Independent variables

\section{A) Financial constraints}

To measure this variable five indexes exist:

1. The size of the company

2. The age of the company

3. Dividend

4. Operating cash flow

5. Long-term loans.

B) Cash assets being held

To measure the variables according to Opler's model following steps must be conducted:

Opler et al. (1999) method is similar to the previous one but in this method the summation of cash and short-term investments are subtracted from the total assets in denominator.

XCASH $=\frac{\text { total cash and short }- \text { term investements }}{\text { total assets }- \text { total cash and short }- \text { term investments - }}$

The bigger this ratio gets, the larger the amount of cash in the company grows.

C) Poor structure of board of directors $A f f \_B d$ The number of common directors (dependent) to all managers;
Ind_Dir the ratio of number of independent members of the Board of Directors to all members;

CEO_duality Is a dummy variable that is 1 if the duties of manager is independent of the duties of the board of director's. Otherwise a zero value is assigned;

CCR CEO salary ratio (CEO) To the total salaries paid to employees;

(M) Managerial entrenchment index is Board Structure Index. To measure this index the model based on the research by Lee and Shiv 2010 will be used:

$M$ anagerial entrenchment index $=* A f f_{-} B d$ $+{ }^{*}$ Ind_Dir $+{ }^{*}$ CEO_duality $+{ }^{*}$ CCR

When the board index $(M)$ is higher.

\section{Control Variables}

CF / Assets: The ratio of earnings before interest and taxes minus dividends paid to a company's assets,

NWC / Assets: The ratio of current assets, except for cash assets of the company;

Industry Sigma: The mean standard deviation of industry cash during the past 5 years,

MV / Assets: The ratio of equity to total assets, book value and market participation,

SalesG: The growth in sales over the past three years, Leverage: Financial leverage,

Dividend: Dividends is a dummy variable that is assigned the value of one if dividend is in the year t Otherwise the value of zero is given to the variable

Age: The number of years that a company is listed

Loan: Accumulated bank debts.

\section{Model of Research}

\section{The first model}

To test the first model (the sensitivity of investment in companies with higher financial pressure to excess) model number one is used: 
$I_{i, t}=b_{0}+b_{1} X \operatorname{Cash}_{i, t-1}+b_{2} Q_{i, t-1}+X_{i, t}+e_{i, t}$

Where: $I_{i}, T$ Corporate capital expenditure of the company i Per year $t$ -

$X$ Cash,$T-1$ excess cash of the company $i$ at the beginning of the year $t$ -

$Q_{i, T-1}$ Ratio of market value to book value of equity at the beginning of the year to control for investment opportunities;

$x i, t$ A set of control variables as follows:

The ratio of earnings before interest and taxes minus dividends paid to a company's assets (CF/Assets), the ratio of current assets, except for cash assets of the company (NWC/Assets), the mean standard deviation of industry cash during the past 5 years (Industry Sigma), The ratio of equity to total assets, book value and market participation (MV/Assets), The growth in sales over the past three years (salesG), financial leverage (leverage), Dividends which is a dummy variable that is assigned the value of one if dividend is in the year t Otherwise the value of zero is given to the variable, the number of years that a company is listed (age), and accumulated bank debts (Loan) are the control variables.

The second model

To test the second model (the sensitivity of investment in companies with poor management structure to excess cash) model number two is used:

$I_{i, t}={ }^{\beta}{ }_{0+} \beta_{1 F C_{i,-1}+}{ }^{\beta}{ }_{2 X C^{2} a s h i, t 1-1} * F C_{i, t-1+}{ }^{\beta}{ }_{3 M_{i, t}}$ ${ }_{1+}{ }^{\beta}{ }_{4} X \operatorname{Cash}_{i, t-1} * M_{i, t-1}+{ }_{5} Q_{i, t 1}+X_{i, t}+e_{i, t}$

$\mathrm{FC}_{\mathrm{i}, \mathrm{T}-1}$ Index of financial constraints;

$\mathrm{M}_{\mathrm{i}, \mathrm{T}-1}$ Poor indicators of board structure (corporate governance);

$\mathrm{XCash}^{*} \mathrm{FC}$ to test the relationship between excess cash and the financial crisis;

$X$ Cash $* M$ to examine the relationship between board structure and excess cash

$Q_{i, T-1}$ Ratio of market value to book value of equity at the beginning of the year to control for investment opportunities;

$x, t \mathrm{R}$ is a set of control variables.

Results

Descriptive Statistics

Descriptive statistics for the study are described below.

\begin{tabular}{|l|r|r|r|r|r|r|r|r|}
\multicolumn{1}{l|}{} & $\mathrm{N}$ & & & \multicolumn{1}{c|}{ Statistics } \\
\cline { 2 - 8 } & Valid & Mean & Median & $\begin{array}{c}\text { Std. } \\
\text { Deviation }\end{array}$ & Skewness & Kurtosis & Minimum & Maximum \\
\hline Imvestment & 624 & .0524 & .0330 & .06478 & 3.385 & 17.563 & .00 & .62 \\
XCASH 1-1 & 624 & .0751 & .0435 & .10157 & 4.064 & 24.320 & .00 & .95 \\
FCF & 624 & .0772 & .0752 & .05943 & -.034 & 5.686 & -.27 & .45 \\
NWCA & 624 & .5715 & .5916 & .20273 & -.461 & -.573 & .07 & .93 \\
IND_SIGMA & 624 & .0340 & .0344 & .01480 & 2.125 & 6.774 & .01 & .10 \\
MB & 624 & 2.2430 & 1.6552 & 4.72303 & 8.877 & 187.590 & -44.09 & 87.07 \\
SaleG & 624 & .2027 & .1452 & .22098 & 6.405 & 80.087 & .00 & 3.49 \\
LEV & 624 & .6290 & .6256 & .21153 & 2.366 & 19.911 & .10 & 2.76 \\
Dividend & 624 & .86 & 1.00 & .348 & -2.068 & 2.283 & 0 & 1 \\
AGE & 624 & 15.56 & 14.00 & 8.995 & 1.607 & 2.046 & 6 & 44 \\
LOAN & 624 & .2698 & .2329 & .19234 & 2.585 & 19.190 & .00 & 2.25 \\
Qt-1 & 624 & 2.5827 & 1.8061 & 4.56708 & -.231 & 49.345 & -44.09 & 42.05 \\
\hline
\end{tabular}

As you can see the skewness and elongation is low in the variables which shows that the distribution of the variables is symmetrical and very close to normal distribution

Cone

of the main assumptions for using regression). As you can see in the table above the average investment in the 
sample is 0.0524 which means that averagely $5 \%$ of total assets in the sample are invested in each year. Median value of the variable investment equals 0330/0, which alongside the fact that it is not even close to the mean and regarding the skewness and elongation, it shows that the distribution for this variable is not normal. Other findings show that excess cash (XCASH) in the companies in question is 0.0751 . Also the average ratio of gross earnings before interest and tax (FCF) is 0.0772 . Other findings show that the average current assets (except for cash) to the total assets (NWCA) is 0.5715 and standard deviation for the cash in the industry for five years (IND_SIGMA) is 0.0340 .
MB (market value to book value) in the sample is 2.2430 and the average sale growth (SalesG) is 0.2027 which shows the incremental growth for the sample. The average financial leverage (leverage) in these companies was 0.6290 which shows that nearly $63 \%$ of the resources needed by the company are provided through loaning. The average long-term debts was 0.2698 which shows that $27 \%$ of the financial resources are provided by longterm loans from the banks.

\section{Assumptions for Regression}

Using Kolmogorov- Smironov test the normality of investment variable as the dependent variable is assumed.

\begin{tabular}{|c|c|c|c|c|c|c|c|c|}
\hline \multicolumn{9}{|c|}{ One-Sample Kolmogorov-Smirnov Test } \\
\hline & \multirow[b]{2}{*}{ YEAR } & \multicolumn{2}{|c|}{ Normal Parameters $^{a}$} & \multicolumn{3}{|c|}{ Most Eđreme Differences } & \multirow{2}{*}{$\begin{array}{l}\text { Kolmogoroy } \\
\text {-Smirnov }\end{array}$} & \multirow{2}{*}{$\begin{array}{c}\text { Asymp. Sig } \\
\text { (2-tailed) }\end{array}$} \\
\hline & & Mean & $\begin{array}{c}\text { Std. } \\
\text { Deviation }\end{array}$ & Absolute & Positive & Negative & & \\
\hline \multirow[t]{7}{*}{ Investment } & 1384 & .0894 & .10933 & .217 & .217 & -207 & 1.987 & .001 \\
\hline & 1385 & .0608 & .06513 & .188 & .188 & -166 & 1.863 & .002 \\
\hline & 1386 & .0670 & .06991 & .200 & .200 & -.174 & 1.767 & .004 \\
\hline & 1387 & .0558 & .05434 & .168 & .168 & -.152 & 1.429 & .034 \\
\hline & 1388 & .0343 & .04102 & .206 & .179 & .206 & 1.982 & .001 \\
\hline & 1389 & .0344 & .03485 & .188 & .188 & -164 & 1.880 & .002 \\
\hline & 1390 & .0341 & .03411 & .164 & .149 & -.164 & 1.634 & .010 \\
\hline \multirow[t]{7}{*}{ LOG_Imvestment } & 1384 & -1.3238 & .56261 & .095 & .045 & -.095 & .867 & .439 \\
\hline & 1385 & -1.4866 & .58816 & .101 & .052 & -101 & .991 & .280 \\
\hline & 1386 & -1.3965 & .48797 & .070 & .043 & -.070 & .616 & .843 \\
\hline & 1387 & $-1,4927$ & .58147 & .128 & .097 & -128 & 1.082 & .192 \\
\hline & 1388 & -1.6985 & .47904 & .067 & .047 & .067 & .649 & .793 \\
\hline & 1389 & -1.7030 & .52537 & .088 & .050 & -088 & .876 & .426 \\
\hline & 1390 & -1.7026 & .52481 & .121 & .068 & -121 & 1.208 & .108 \\
\hline
\end{tabular}

The significance level in $\mathrm{KS}$ in Kolmogorov- Smironov test is less than 5\% in all the years of interest. In this test, if the level of significance is less than $5 \%$ in a year we conclude that the distribution of the variable is not normal in that year. To fix this problem we took the logs of the investment variable.

Findings from the KolmogorovSmironov test of investment logs show that the significance level for KS is more than $5 \%$ in all the years of interest which in turn shows that in those years the distribution of the variable is normal and the remaining values on the regression line are normally distributed too, and there is probably no anisotropy in the variances (the combination of normally distributed elements is normal). 
In the histogram below the distribution of investment can be seen before (on the

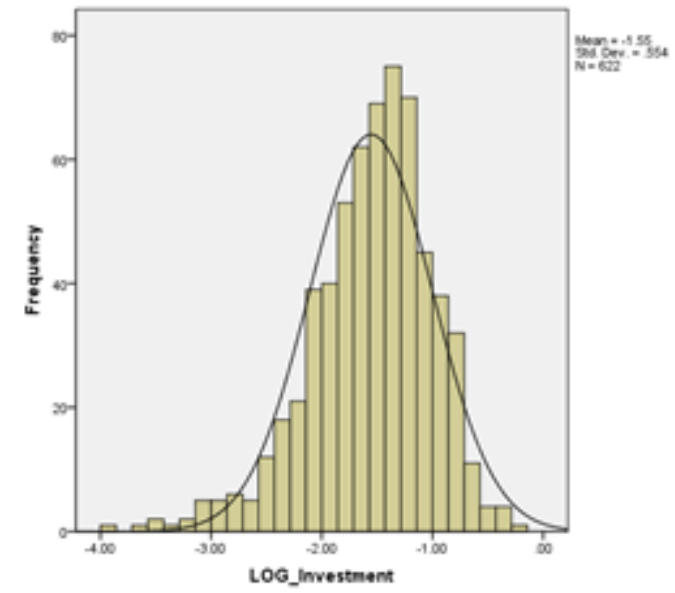

left) and after (on the right) normalization.

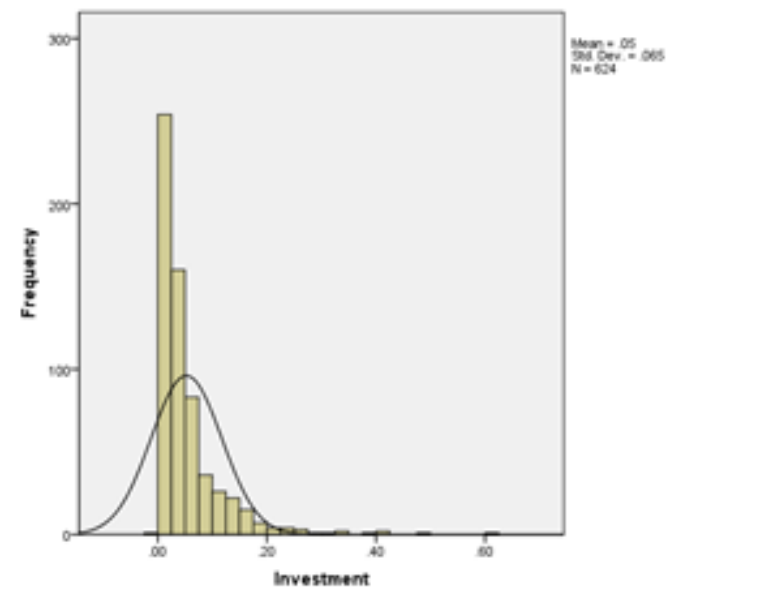

\section{Testing Normality of the Errors}

Distribution of errors is so close to the normal. Also the mean and standard deviation are so close to those of normal distribution ( 0 and 1 respectively). So this assumption is satisfied and regression can be used in further analyses.

\section{The Co-line Test}

The relationship between cash holdings at the beginning of the period (XCASH) and investment expenses (investment) are positive and probably significant and the relationship between FC (financial constraints) and investment (investment expenses) are negative and probably significant.

The relationship between the ratio of market value to book value $(Q)$ and earnings before interest and tax and after dividend (FCF) with investment expenses (investment) are positive and probably significant.

The relationship between non-cash working assets and investment is negative and probably significant and the relationship between standard deviation (dispersion), the amount of cash held in the industry (IND_SIGMA), and investment is positive and probably insignificant.

The relationship between the ratio of market value to book value (MB) and investment (Investment) is significant and positive and the relationship between sales growth (SaleG) and made capital expenditures (Investment) appears to be negative and probably meaningless.

Relationship between financial leverage (LEV) and the amount invested (Investment) is significant and likely to be negative. The relationship between dividends paid (Dividend) and investment is seen as positive.

The relationship between age (AGE) and investment (Investment) is positive (direct) and probably meaningless and the relationship between long-term loans (LOAN) and capital expenditure seems to be quite negative and significant.

The statistic value of $\mathrm{F}$ in this model equals 14.905 and significance level (SIG) is 0.000 which means there is a linear relationship between dependent and independent variables. In other words this 
model is significant, and the hypothesis can be tested using regression model.

Determination coefficient in this model is 0.212 which means about $21 \%$ of the changes in dependent variable are explained by dependent variables. Dorbin Watson statistic value is 1.990 which shows the lack of self-correlation in the model being used.

- Statistic value of $\mathrm{T}$ and the significance level (sig) for excess cash holdings at the beginning of the period (XCASH) are respectively 998/1 and 044/0. The impact of these variables on the rate of investment has been significant. So we can say that, by the confidence level of 95\%, excess cash holdings at the beginning of the period, have a significant positive impact on the level of capital expenditure (Investment).

\section{Summary of Results of the Research Hypotheses}

Summary of results of the first hypotheses Summary results of the first hypothesis using firm size as a measure of financial constraints

Statistic value of $\mathrm{F}$ in this model for the companies without financial constraints in 12.025 and significance level is 0.000 and for those with financial constraints 5.776 and 0.000 are the values of $F$ and significance respectively. So the model is significant.

Determination coefficient in the companies with and without financial constraint is 0.175 and 0.307 respectively. It means that 31 and $18 \%$ of the changes in the dependent variable is explained by the independent variables respectively in companies without and with financial constraint.

Statistic value of $\mathrm{T}$ and the significance level for the excess cash holdings is 2.640 and 0.009 respectively for the companies without financial constraint which shows the positive and significant impact of this variable on the level of investment.

The statistic value of $\mathrm{T}$ and the significance level for the companies with financial constraint is -0.093 and 0.926 respectively which shows the lack of significant effectiveness on the investment expenses.

In conclusion the first hypothesis implying that investment sensitivity in companies with more financial constraints is more regarding excess cash holdings is not approved.

Summary results of the first hypothesis, using age as a measure of financial constraints

Statistic value of $\mathrm{F}$ in this model for the companies without financial constraints in 4.430 and significance level is 0.000 and for those with financial constraints 16.750 and 0.000 are the values of $F$ and significance respectively. So the model is significant.

Determination coefficient in the companies with and without financial constraint is 0.392 and 0.135 respectively. It means that 14 and $39 \%$ of the changes in the dependent variable is explained by the independent variables respectively in companies without and with financial constraint.

Statistic value of $\mathrm{T}$ and the significance level for the excess cash holdings is $\mathbf{1 . 1 5 6}$ and 0.249 respectively for the companies without financial constraint which shows the positive and insignificant impact of this variable on the level of investment.

The statistic value of $\mathrm{T}$ and the significance level for the companies with financial constraint is 0.845 and 0.394 respectively which shows the lack of significant effectiveness on the investment expenses.

In conclusion the first hypothesis implying that investment sensitivity in companies with more financial constraints 
is more regarding excess cash holdings is not approved.

Summary results of the first hypothesis using dividends as a measure of financial constraints

Statistic value of $\mathrm{F}$ in this model for the companies without financial constraints in 10.368 and significance level is 0.000 and for those with financial constraints 2.621 and 0.008 are the values of $F$ and significance respectively. So the model is significant.

Determination coefficient in the companies without and with financial constraint is 0.175 and 0.321 respectively. It means that 17 and $32 \%$ of the changes in the dependent variable is explained by the independent variables respectively in companies without and with financial constraint.

Statistic value of $\mathrm{T}$ and the significance level for the excess cash holdings is 1.653 and 0.099 respectively for the companies without financial constraint which shows the positive and insignificant impact of this variable on the level of investment.

The statistic value of $\mathrm{T}$ and the significance level for the companies with financial constraint is -0.8367 and 0.715 respectively which shows the lack of significant effectiveness on the investment expenses.

In conclusion the first hypothesis implying that investment sensitivity in companies with more financial constraints is more regarding excess cash holdings is rejected.

Summary results of the first hypothesis using cash flows as a measure of financial constraints

Statistic value of $\mathrm{F}$ in this model for the companies without financial constraints in 8.285 and significance level is 0.000 and for those with financial constraints 4.017 and 0.000 are the values of $F$ and significance respectively. So the model is significant.

Determination coefficient in the companies without and with financial constraint is 0.234 and 0.129 respectively. It means that 23 and $13 \%$ of the changes in the dependent variable is explained by the independent variables respectively in companies without and with financial constraint.

Statistic value of $T$ and the significance level for the excess cash holdings is 0.814 and 0.411 respectively for the companies without financial constraint which shows the positive and insignificant impact of this variable on the level of investment.

The statistic value of $\mathrm{T}$ and the significance level for the companies with financial constraint is 0.263 and 0.793 respectively which shows the lack of significant effectiveness on the investment expenses.

In conclusion the first hypothesis implying that investment sensitivity in companies with more financial constraints is more regarding excess cash holdings is rejected.

Summary results of the first hypothesis using long-term loans as measure of financial constraints

Statistic value of $\mathrm{F}$ in this model for the companies without financial constraints in 12.661 and significance level is 0.000 and for those with financial constraints 5.216 and 0.000 are the values of $F$ and significance respectively. So the model is significant.

Determination coefficient in the companies without and with financial constraint is 0.318 and 0.161 respectively. It means that 32 and $16 \%$ of the changes in the dependent variable is explained by the independent variables respectively in companies without and with financial constraint. 
Statistic value of $\mathrm{T}$ and the significance level for the excess cash holdings is $\mathbf{1 . 6 4 6}$ and 0.099 respectively for the companies without financial constraint which shows the positive and insignificant impact of this variable on the level of investment.

The statistic value of $\mathrm{T}$ and the significance level for the companies with financial constraint is 0.962 and 0.337 respectively which shows the lack of significant effectiveness on the investment expenses.

In conclusion the first hypothesis implying that investment sensitivity in companies with more financial constraints is more regarding excess cash holdings is rejected.

\section{The Overall Conclusion on the First Hypothesis}

According to the five part analyzed above one could in overall say that the first hypothesis implying that investment sensitivity in companies with more financial constraints is more regarding excess cash holdings is rejected with the confidence level of $95 \%$.

\section{Summary of Results of the Second Hypothesis}

Statistic value of $F$ in this model and significance level are 13.192 and 0.000 respectively and whereas this value is more than 0.05 the model is significant.

Determination coefficient is 0.246. It means that $25 \%$ of the changes in the dependent variable is explained by the independent variables.

Statistic value of T-student and the significance level for management structure is 2.097 and 0.036 which shows that management structure positively and significantly affects the level of investment in the companies so that when management gets stronger, investment expenses increase.
But the statistic value of student-T and the significance level for the interactional variables of excess cash holding and management structure are -0.739 and 0.460. the fact that the value for $t$ is negative suggests that strengthening the structure of the board of directors (increasing the variable $\mathrm{M}$ ), lowers the sensitivity of investment level to excess cash holdings, nevertheless this relationship is statistically insignificant.

Therefore enough evidence is not provided regarding the fact that sensitivity of investment is influenced by management structure and excess cash and this hypothesis is rejected with a confidence level of $95 \%$.

\section{Suggestions}

Regarding the results from the first hypothesis and the higher sensitivity in the companies with financial constraints toward excess cash holdings, and regarding the fact that managers in companies where there are more cash flows, are more likely to get involve in investment activities which are not always profitable it is suggested that more attention is paid to the projects with negative values which will lead to big problems for the company and invest more carefully. An optimized level for cash holdings and investment is also suggested. Concerning the results from the second hypothesis, it is suggested that companies start strengthening their management structures and use independent, qualified, and skilled managers alongside with other factors affecting improvement of board of directors' structure.

\section{References}

Ahmadpoor, A. and Rsayyan, A. (1385). Erroneous, and the difference between the cost price Buying and selling shares 
in investment funds, Joint Conference Papers Billing Kashan University, 106-89.

Azar, A. and M. Momeni (1387). Application of Statistics and Management. (Eleventh edition), Tehran: the side.

Arooji, A. (1389). The relationship between deviations from expected cash company operating performance and stock returns, MSc thesis, university.

Aqaee, M.A., Pep, P. (1388). Examined the relationship between corporate governance characteristics and earnings management of listed companies in Tehran Stock Exchange, Quarterly - Winter Special Accounting Research 88.

Aqaee, M.A., $\quad$ Cleaning, A.R., Nazemi Ardakani, M. and Young, A. A. (1388). Factors

Affecting Maintenance Inventories Cash th e companies listed in stock Papers Tehran Stock "Research, Financial Accounting, 1(1 and 2), 53-70.

Corporate Governance Regulations Tehran Stock Exchange (1386) (Adopted by the Board of Tehran Stock Exchange.

Badri and Skini, (1391). Experimental test of reverse investment strategy using data envelopment analysis: Journal of Accountancy, 3, 137-156.

Bolo, G. (1391). The relationship between more and less than optimum cash, future performance of listed companies in Tehran Stock Exchange, Journal of Accounting, 3(11), 7-29.

Tehrani R. and Hesarzade M. (1388). The impact of the Cash Free And Limitations A Security Financial The more Capital Forums And Low Investment "Accounting Research, 3, 3.
Tehrani R. and R. Hesarzade M.

(1388). The impact of the Cash Free And Limitations At Security Financial The more Capital Forums And Low Investment "Accounting Research, 3, 3.

Saghafi, A., Bolo, G., Mohammadian, and M. (1390). Quality of Accounting Information, invest too much free cash flow, Accounting Developments, 3(2), 37-63.

Saghafi, A. and Arab Mazar Yazdi, M. (1389). Financial reporting quality and investment inefficiency, Journal of Financial Accounting, Second Year, 4(6).

Hasas Yegane, Y. The impact of corporate governance on the development of capital markets in some countries.

Hasas Yegane, Y. (1385). Corporate Governance in terms of doctor-Hasas Yegane, Journal of Auditors, 32.

Hasas Yegane, Y. The impact of culture on corporate governance systems, in South Korea, the influence of philosophy Confucius.

Hasas Yegane, Y. and Al, A. (1385). The challenges of corporate governance in Iran's capital market system.

Hasas Yegane, Y., Nader Noeiny, M. (1386). Corporate Governance Lessons fro $\mathrm{m}$ the Collapse of Enron.

Hasas Yegane, Y. and Kheirollahi, M. (1388). Corporate governance and transparency, Accounting, 23(203).

Khajavi, Sh. And Bayazidi, A. (1391). Investigated the relation between accruals quality and maintenance of the cash assets of listed companies in Tehran Stock Exchange, Journal of Accounting, 3(9), 5576. 
Rahimiyan, N. and Kakavand, H. (1391). Maintains a cash and stock portfolio returns, Financial Accounting Research, 2(1), 78-97.

Rahimiyan, N. Kakavand, H., and Hassan Zadeh, M. (1391). Cash holdings and return on equity portfolio, Imam University Journal of Professional Accounting, 1(3), 78-92.

Rsayyan, A., Rahimi, F., and Hanjry, S. (1389).Effect Mechanisms Regulatory Insi de Corporate governance Company On Level Maintenanc e Payment

Review Instock Papers Stock Tehran, Financial accounting research, second, fourth Number, Serial No. 6, 144-125.

Saleki, A. (1388). Information Asymmetry and Corporate Governance, Quarterly Review of Accounting and Auditing, 58(16).

Saleki, A. and Rahimiyan, N. (1388). The relationship between corporate governance mechanisms and asymmetry of the companies listed in Tehran Stock Exchange (Thesis).

Setayesh, M.H. and Jamalian Pour, M. (1389). Presence of conservatism in financial reporting of listed companies in Tehran Stock Exchange, Advances in Accounting (Social Sciences and Humanities Library), 2 (1) (s 3/58), 85119.

Sharifi, S. and Aqae, M.A. (1389). Effect of the amount of cash kept on the company's future performance, master's thesis, University of Mazandaran.

Shorvarzy, M.R. and Barzegar Khandozy, A. (1388). The role of information and information asymmetry being conservative, CPA Journal, 24 (210), 56-63.
Talebi, M. (1377). Evaluation Status the Management Current capital at Companies, Iran monograph PhD Accounting from School University of Management Tehran.

Talebi, M. (1377). Evaluation of Status of the Management Current capital at Companies Iran "monograph PhD Accou nting from School University of Management Tehran.

Fakhari H. and Taghavi, R.N. (1388). Quality Items Accrual and Remained Paym ent Review of Survey of Accounting and Auditing, 16(57), 84-69.

Falah Shams M.F. and Kosha, K. Review on Research Performance by at Background Returns Abnormal, Informa tion Financial PublishedAnd Relations Bet ween

them At Companies Accepted By At Exchan ge Papers Stock Tehran "Page 5.

Ghaemi, M.H. and Alavi, M. (1390). Relationship between Transparency Infor mation Accounting and Inventory Review, Journal Scientific Research

Accounting Management in V, Number XII, 78-67.

Kashani Pour M.N. and Race, B. (1388). Survey Effect Limitations the Financial on Sensitivity Cash flow Payment Review of Research Accounting, No. II, 72-93.

Canaanite Amiri, M. (1386). Examined the relationship between financial constraints and stock returns in the capital markets of Iran, Persian date Dey 1386 Journal Fourteenth Year No. 26.

Mahmoodabadi, H. and Mehtari, Z. (1390). The relationship between accounting conservatism and investment efficiency companies listed in Tehran Stock 
Exchange, Journal of Accounting Achievement, Third Year, 2 (61).

Modarres, A. and Hesarzadeh, R. (1387). Financial reporting quality and investment efficiency, Quarterly Stock Exchange, 1(2).

Modarres, A. and Dianati, Z. (1382). Application of multivariate time series models in forecasting operating cash flow, accounting and audit review, 34(10), pp. 77-110.

Modarres, A. and Asgari, M., Identification Factors Effective On Efficien cy Abnormal Long-term Shares

offered Public Primary At Exchange Papers Tehran Stock Quarterly Exchange Papers Securities.

Moradzadeh Fard, M., Nazmi Ardakani, M., Gholami, R., and Farzan, H. Ullah (1388). Examined the relationship between institutional ownership and management interest in the shares of listed companies in Tehran Stock Exchange of accounting and auditing, No. 55.

Sheikhs, SH, and Ismaili, M. (1385). Relationship between earnings quality and some aspects of strategic principles in companies listed in Tehran Stock Exchange, Journal of Accounting. And Auditing, 45, 25-44.

Mehran, S., Kashani Pour M., and Rsayyan, A. (1388). Factors Determining Capital Structure at Iran, Quarterly Research Letter Economic SupplementStock, 125151.

Mehran, K. and Fence Zadeh, R. (1388). The quality of accounting and cash holdings. Quarterly Exchange Papers Securi ties, 2(5).

Mehran, K. and Fence Zadeh, R.
Quality and Level Maintenance Fund Review, Quarterly Exchange Papers Securities, 2(5).

Harati, H. (1390). The effect of stock returns on excess cash. end Letter Bachelor International University Imam Khomeini.

Harati, $\mathrm{H}$. (1390). Effect Payment Review Surplus The Return Shares Companies' end Letter Bachel or International University Imam Khomeini.

Ball, R. and Shivakumar, L. (2005). Earnings quality in UK private firms: comparative loss recognition timeliness, Journal of accounting and economics, 39(1), 83-128.

Barclay - M. and Smith - C. Jr. - (1995). The Athurity Structure of Corporate Debt, Journal of Finance, 50, 609.

Basu, S. (1997). The conservatism principle and the asymmetric timeliness of earnings.Journal of Accounting and Economics, 24, 3-37.

Bushee, B.J. (1998). The Influence of institutional investors on myopic $\mathrm{R}$ \& D investment behavior, Accounting Review, 73, 305-334.

Dittmar, A., Mahrt-Smith, J., and Servaes, H. (2003). International Corporate Governance and Corporate Cash Holdings, Journal of Financial and Quantitative Analysis, 38, 111 133.

Drobetz, W., Gruninger, M. and Hirschvogl, S. (2010). Information Asymmetry and the Value of Cash, Journal of Banking \& Finance, 34, 2168-2184.

Ferreira, M.A. and Vilela, A. (2004). Why Do Firms Hold Cash? Evidence from EMU Countries, European Financial Management, 10(2), 295. 
Foust D. (2004). Making a Pile on Cash - Rich Companies. Business Week, (December 27), 122-125.

Garcia-Teruel, P.J. and Martinez-Solano, P. (2008). On the Determinants of SME Cash Holdings: Evidence from Spain, Journal of Business Finance and Accounting, 35, 127 149.

Garcia-Teruel, P.J., Martinez-Solano, P. Sanchez-Ballesta, J.P. (2009). Accruals Quality and Corporate Cash Holdings, Journal of Accounting and Finance, 49, 95 - 1 15,

Yilmaz-Ozkan, G. and Ozkan Neslihan, A. (2003). Additional International Evidence on Corporate Cash Holdings, available at www.ssrn.com, id = 406721 .

Harford, J., Mansi, S.A., and Maxwell, W.F. (2008). Corporate Governance and Firm Cash Holdings, Journal of Financial Economics, 87, 535-555.

Jani, E. and Hoesli, M. B. (2004). Corporate Cash Holdings and Agency Conflicts, available at www.ssrn.com, id $=563863$.

Jensen, M. (1986). Agency costs of free cash flow, corporate finance, a takeovers. American Economic Review, 76, 323-329.

Jensen, M.C. and Mackling, W.H. (1976). Theory of the Firm Managerial Behavior. Agency Costs and Ownership Structure, Journal of Financial Economic, 3(4), $305-360$.

Kim, C.S., Mauer, D. and Sherman, A.E. (1998). The Determinants of Corporate Liquidity: Theory and Evidence, Journal of Financial and Quantitative Analysis, 33, 335359.

Lee, C.F. (2009). Cash Holdings, Corporate Governance Structure and Firm Valuation,
Review of Pacific Basin Financial Markets and Policies, 12(3), 475-508.

Li, K.K. (2007). Expected holding of cash, future performance and stock return". SSRN: http://ssrn.com/abstract=121 4962 - Working Paper Series.

Michalski, G. (2010). Planning Optimal from the Firm Value Creation Perspective Levels of Operating Cash Inventoress. Romanian Journal of Economic Forecasting.

Myers, S.C. and Majluf, N.S. (1984). Corporate financing and investment decisions when firms have information that investors do not have. Journal of Financial Economics, 20, 293-315.

Tim, O., Lee, P., Reneh, S., and Rohan, W. (1999). The Determinants and Implications of Corporate Cash Holdings, Journal of Financial Economics, 52, 3-46.

Aydin, 0. and Neslihan, 0. (2004). Corporate Cash Holdings: An Empirical Investigation of UK Companies, Journal of Banking \& Finance, 28, 2103 - 2134.

Venkat, S., Tang, Heng T.T., and Xin Zhou, Y. (2011). Firm structure and corporate cash holdings. Journal of Corporate Finance, 17, 759-773.

Swanson, Z., and Alltizer, L. (2010). Cash Position Forecasts and Stock Market Portfolio Returns. www.SSRN.com.

Titman. SH. and Wessels, R. (1988). The Determinants of Capital Structure Choice, Journal of Finance, 43(1).

Verdi, R.S. (2006). Financial Reporting Quality and Investment Efficiency. Available at www.ssrn.com.

Watts, R.L. (2003). Conservatism in accounting, Part I: Explanations and 
implications, Accounting Horizons, 17(3), 207-221.

Yu, F. (2005). Accounting transparency and the term structure of credit spreads, Journal of Financial Economics, 75, 53-84.

Yuanto, K. (2011). Do corporate governance mechanisms matter for cash holdings and firm value? Journal of Corporate Finance, 17, 725 - 7 [40].

Ziobrowski, A. (2004). Abnormal Returns from the Common Stock Investments of the US Senate, Journal of Financial \& Quantitative Analysis, Vol. 39(4), 1-16.

How to cite this article: Hossein Rahmandost, Dr. Ali Faez, The Impact of Financial Constraints and Managerial Entrenchment on the Relationship between Excess Cash Holdings and Investment. International Journal of Advanced Studies in Humanities and Social Science, 2019, 8(1), 104-118.

http://www.ijashssjournal.com/article 84113.html 